\title{
RESILIENSI KELUARGA : TEORI, APLIKASI DAN RISET
}

\author{
Ike Herdiana \\ Universitas Airlangga Surabaya \\ ike.herdiana@psikologi.unair.ac.id
}

\begin{abstract}
ABSTRAK
Tujuan dari artikel ini adalah menjelaskan bagaimana resiliensi keluarga dijelaskan sebagai sebuah konsep dan terapan pada penelitian maupun layanan psikologis kepada masyarakat. Metode yang digunakan dalam kajian ini adalah mengumpulkan kepustakaan atau hasil bacaan sebagai sumber sekunder yang terdapat dalam artikel jurnal ilmiah. Data yang ada dalam setiap artikel kemudian di pilah sesuai dengan relevansinya dan dilakukan analisis terhadap konten untuk melihat kesesuaiannya. Hasil telaah literature adalah : (1) Sebagai sebuah konsep, resiliensi dipandang dari beberapa perspektif. Dalam pandangan tradisional, resiliensi keluarga merupakan jumlah dari ketahanan anggota keluarga. Sebuah perspektif kontemporer memandang resiliensi keluarga dengan memberikan penekanan pada sifat relasional dari keluarga sebagai sebuah unit; (2) Kerangka resiliensi keluarga sangat relevan dengan praktik klinis dan pemberian layanan sosial. Menurut definisinya, resiliensi melibatkan kekuatan di bawah tekanan akibat krisis dan kesulitan yang berkepanjangan. Berbeda dengan fokus praktik deficit model, pendekatan yang berorientasi pada resiliensi ini menarik keluar kekuatan dan potensi keluarga untuk menghadapi tantangan. Selain mengatasi masalah, resiliensi juga melibatkan transformasi dan pertumbuhan positif. Dalam membangun ketahanan relasional, keluarga membentuk ikatan yang lebih kuat dan menjadi lebih banyak solusi dalam menghadapi tantangan masa depan. Jadi, setiap intervensi memiliki manfaat pencegahan; (3) Penelitian tentang resiliensi keluarga menjadi sangat menarik. Peneliti didorong untuk mampu mengidentifikasi dan mendorong perilaku yang memungkinkan keluarga mengatasi secara efektif krisis, trauma dan tekanan yang dialami keluarga.
\end{abstract}

Keywords : Resiliensi keluarga, Teori, Aplikasi, Riset

\section{PENDAHULUAN}

Resiliensi merupakan kemampuan seseorang untuk pulih dari krisis dan tantangan yang ditemui dalam hidup. Tidak hanya individu, saat ini keluargapun memiliki pengalaman-pengalaman yang sangat menantang atau situasi krisis yang disebabkan oleh beragam hal. Tidak ada keluarga yang luput dari masalah, hanya saja ada masalah yang lebih mudah diatasi dan sifatnya tantangan, namun ada masalah yang lebih berat yang menimbulkan krisis. Hal yang menarik dari resiliensi keluarga ini adalah bagaimana anggota keluarga saling memberikan dukungan saat terjadinya masalah dalam keluarga. Lalu bagaimana pula keluarga menyelesaikan masalahnya. Bagaimana keluarga membangun kembali kehidupan setelah terjadi transisi. Sangat penting untuk memahami bagaimana keluarga 
dapat mengintegrasikan secara efektif pengalaman-pengalaman menakutkan dan melanjutkan kehidupannya dengan penuh cinta (Walsh, 2006).

Sebagai sebuah konsep, resiliensi keluarga juga menarik untuk dikaji lebih dalam baik melalui penelitian ataupun aplikasinya dalam pelayanan psikologi bagi keluarga. Menariknya, resiliensi keluarga menunjukkan peristiwa yang unik dimana saat keluarga menjadi terpecah belah oleh krisis atau tekanan yang terjadi terus menerus, beberapa keluarga justru menjadi lebih kuat dan bijaksana. Peneliti kemudian menjadi focus pada bagaimana sebuah keluarga bisa tetap berfungsi secara positif dan menjadi resiliens, ditengah masalah bertubi-tubi yang menderanya (Walsh, 2006). Walsh juga memberikan gambaran tentang family therapy, yang mana telah muncul sejak akhit tahun 1960 an. Awalnya penelitian tentang keluarga terfokus pada defisit keluarga, yang diceriminkan melalui pandangan budaya dan media yang lebih luas bahwa sebagian besar keluarga mengalami disfungsional. Walsh kemudian meneliti tentang keluarga pada program yang diadakan untuk penderita skizofrenia dan menemukan bahwa ada keluarga yang tetap normal meski ada anggota keluarga yang menderita gangguan mental.

Artikel ini akan menjelaskan bagaimana resiliensi keluarga dijelaskan sebagai sebuah konsep dan terapan pada penelitian maupun layanan psikologis kepada masyarakat.

\section{METODE}

Metode yang digunakan dalam kajian ini adalah mengumpulkan kepustakaan atau hasil bacaan sebagai sumber sekunder yang terdapat dalam artikel jurnal ilmiah. Pencarian data dilakukan melalui Google, Google Scholar, Research Gate dan web resmi APA. Data yang ada dalam setiap artikel kemudian di pilah sesuai dengan relevansinya dan dilakukan analisis terhadap konten untuk melihat kesesuaiannya. Tema yang kurang berkaitan untuk sementara di pisahkan dan tidak menjadi bagian yang dianalisis. Namun demikian, ketika ditemukan tema yang dapat memberikan informasi baru, meski di luar pertanyaan khusus, tetap menjadi catatan bersamaan dengan tema utamanya. Terakhir peneliti membuat kesimpulan atas semua informasi atau data yang telah dikumpulkan.

\section{HASIL TELAAH LITERATUR}

\subsection{Konsep Tentang Resiliensi Keluarga}

Sebagai sebuah konsep, resiliensi kemudian dipandang dari beberapa perspektif. Perspektif konsep resiliensi berkembang sejak konsep tersebut diperkenalkan sebagai konstruk pada level keluarga. Dalam pandanga 
tradisional, resiliensi keluarga merupakan jumlah dari ketahanan anggota keluarga. Sebuah perspektif kontemporer memandang resiliensi keluarga dengan memberikan penekanan pada sifat relasional dari keluarga sebagai sebuah unit. Perspektif tersebut juga memandang proses relasional yang memfasilitasi kelangsungan hidup dan pertumbuhan keluarga di bawah kondisi yang tidak menguntungkan. Perubahan besar yang terjadi pada perkembangan konsep resiliensi keluarga adalah cara pandang yang berbeda tentang resiliensi keluarga sebagai sebuah sifat dan resiliensi keluarga sebagai sebuah proses. Peneliti kemudian membuat dua kubu dalam penyelidikannya. McCubbin dan McCubbin menggunakan resiliensi keluarga dari sudut pandang dimensi, sifat yang dimiliki keluarga untuk memiliki ketahanan terhadap situasi krisis. Sementara Patterson adalah peneliti yang menggunakan konsep resiliensi keluarga melalui sudut pandang proses, yaitu melihat kemampuan keluarga memobilisasi kekuatan secara aktif saat mengalami krisis, dimana kondisi tersebut memungkinkan keluarga dapat berfungsi kembali seperti sedia kala sebelum stressor atau krisis dialami. Namun demikian, saat ini penelitian terbaru tentang resiliensi keluarga cenderung menekankan interaksi dari sudut pandang sifat dan proses, sehingga menghasilkan sebuah pemahaman yang holistis (Herdiana, Suryanto, \& Handoyo, 2018)

Pada literatur yang lain, disebutkan bahwa konsep resiliensi keluarga merupakan topik bahasan pada masa psikologi kontemporer (Luthar,Cicchetti\&Becker, 2000). Penelitian sudah banyak dilakukan untuk mengkaji konsep resiliensi keluarga ini, dimana bicaa mengenai bagaimana sebuah keluarga mampu menjalankan fungsinya sebagai tempat untuk memberikan kasih sayang, keamanan, perlindungan, dukungan antara satu sama lain, meskipun dihadapkan pada sebuah stressor yang mengakibatkan keluarga dalam kondisi krisis. Pengertian resiliensi keluarga merupakan suatu cara atau strategi yang dilakukan oleh keluarga dalam menghadapi tekanan, permasalahan atau konflik yang timbul. Keberhasilan dari strategi tersebut tergantung dari bagaimana keluarga menilai permasalahan yang dihadapi. Luthar dan koleganya (2000) mengatakan bahwa perspektif mengenai resilienai keluarga merupakan mengenali kekuatan satu sama lain, mampu berdinamika, menjaga hubungan timbal balik untuk menghadapi konflik yang muncul, hingga masalah tersebut menjadi penguat bagi ketahanan keluarga, dan bukan sebagai perusak. Untuk menghadapi keadaan krisis yang menimpa, keluarga harus memiliki sumber daya yang mendukung antara lain : 
Tabel 1. Sumber Daya yang dimiliki keluarga Untuk Mendukung Ketahanan Keluarga Saat Krisis

\begin{tabular}{|c|c|}
\hline Sumber Daya & Penjelasan \\
\hline $\begin{array}{l}\text { Cara pandang yang } \\
\text { positif }\end{array}$ & $\begin{array}{l}\text { Emosi positif seperti rasa kasih sayang, humor, optimism, } \\
\text { solusi yang positif serta sugesti yang menguatkan satu sama } \\
\text { lain akan membuat keluarga menjadi lebih kuat } \\
\text { (Bradbury\&Karney, 2004) }\end{array}$ \\
\hline Spiritualitas & $\begin{array}{l}\text { Keyakinan yang dianut oleh sebuah keluarga dirasa mampu } \\
\text { memberikan sugesti terhadap jalan keluar yang positif bagi } \\
\text { permasalahan yang dialami keluarga (Mahoney, Pargament, } \\
\text { Tarakeshwar\&Swank, 2001) }\end{array}$ \\
\hline $\begin{array}{l}\text { Keterikatan } \\
\text { anggota keluarga }\end{array}$ & $\begin{array}{l}\text { Keterikatan satu sama lain menjadikan keluarga mampu } \\
\text { bekerjsama dan mencari jalan keluar atas permasalahan } \\
\text { yang ada. Koordinasi yang baik, saling menarik dari } \\
\text { keterpurukan satu sama lain memberi dampak yang besar } \\
\text { bagi pemulihan dari konflik. }\end{array}$ \\
\hline Fleksibilitas & $\begin{array}{l}\text { Fleksibilitas mengacu pada kemampuan keluarga untuk } \\
\text { melakukan rebound dan reorganisasi dalam menghadapi } \\
\text { tantangan sambil mempertahankan kontinuitasnya } \\
\text { (McCubbin \& McCubbin, 1988). Mutualitas paling baik } \\
\text { dicapai ketika anggota keluarga memilikipengertian yang } \\
\text { jelas tentang diri mereka sendiri, baik di dalam maupun di } \\
\text { luar konteks keluarga. }\end{array}$ \\
\hline $\begin{array}{l}\text { Komunikasi } \\
\text { keluarga }\end{array}$ & $\begin{array}{l}\text { Komunikasi yang harmonis merupakan inti dari bagaimana } \\
\text { keluarga menciptakan rasa bersama yang bermakna, } \\
\text { mengembangkan strategi penanggulangan masalah dan } \\
\text { menjaga kesepakatan dan keseimbangan (DeFrain,1999). } \\
\text { Walsh (1998) menyebutkan ada tiga aspek penting dalam } \\
\text { komunikasi keluarga yaitu kejelasan, ekspresi emosional } \\
\text { yang terbuka dan pemecahan masalah secara kolaboratif. }\end{array}$ \\
\hline $\begin{array}{l}\text { Manajemen } \\
\text { keuangan }\end{array}$ & $\begin{array}{l}\text { Pengambilan keputusan yang baik dalam pengelolaan } \\
\text { keuangan dengan status ekonomi keluarga dapat } \\
\text { berkontribusi terhadap kesejahteraan keluarga. Tekanan } \\
\text { keuangan keluarga juga dapat memunculkan stress dan } \\
\text { ketegangan dalam keluarga serta berpengaruh terhadap } \\
\text { kesejahteraan emosional dan hubungan interpersonal }\end{array}$ \\
\hline
\end{tabular}


(Mederer,1999; Walsh,2002)

Waktu untuk Menghabiskan waktu bersama keluarga seperti makan bersama bersama, santai bersama dan mengerjakan tugas bersama merupakan cara untuk menciptakan kontinuitas dan stabilitas dalam kehidupan berkeluarga (McCubbin\&McCubbin,1988)

Minat terhadap Rekreasi dan menghabiskan waktu luang bersama keluarga rekreasi berfungsi untuk memfasilitasi kesehatan keluarga. Waktu keluarga yang menyenangkan dapat menghasilkan kelekatan, penghargaan intrinsik, kebahagiaan, pembelajaran, humor, dan kesenangan berbagi pengalaman (Bowlby, 1982; Hill, 1988; Russell, 1996).

Kegiatan ritual dan Fiese dan rekan (2002) melaporkan bahwa kegiatan rutin rutin atau ritual bersama keluarga memberikan kontribusi mengeratkan hubungan keluarga. Keluarga yang memiliki rutinitas bersama cenderung menghasilkan kebiasaan pola asuh anak yang baik dan dapat menstabilkan keluarga daripada keluarga yang tidak memiliki rutinitas. Rutinitas sering menjadi berhenti saat terjadi krisis keluarga, seperti perceraian atau penyakit (Walsh, 1998).

Dukungan sosial Keluarga yang sehat tidak hanya mendapatkan dukungan sosial dari masyarakat, namun juga dapat memberikan dukungan kembali kepada masyarakat. Sistem dukungan keluarga dan kerabat yang luas dapat berinteraksi secara timbal balik untuk memberikan informasi dan berkontribusi pada kesejahteraan orang lain (Luthar et al,2000; Rutter, 1987; Seccombe,2002)

Sumber : Disarikan dari 'A Conceptual Review of Family Resilience Factors' (Black\&Lobo,2008)

Dengan berkembangnya konsep resiliensi keluarga, fokusnya bergeser dari mengidentifikasi faktor kepribadian individu terhadap pengaruh penting hubungan positif dengan keluarga. Resiliensi keluarga merupakan hasil dari relasi keluarga (Patterson, 2002). Luthar dan rekan (2000) berpendapat bahwa proses dinamis resiliensi paling baik dipahami melalui konteks kerangka kerja yang lebih luas dan saling terkait. Black\&Lobo (2008) menyatakan bahwa perspektif resiliensi keluarga adalah mengenali kekuatan orangtua, dinamika keluarga, hubungan timbal balik yang terjadi dalam keluarga dan lingkungan sosial. Pendekatan 
berbasis kekuatan ini mempertimbangkan stressor dan tantangan yang dihadapi keluarga tidak merusak melainkan sebagai peluang untuk membantu penyembuhan dan pertumbuhan (McCubbin \& McCubbin, 1988, 1996;Walsh, 2003b).

Semua keluarga mengalami masalah, atau stres. Stresor merupakan tuntutan yang ditempakan pada keluarga untuk kemudian menghasilkan atau memunculkan potensi perubahan salam system keluarga (McCubbin \& McCubbin, 1993, hlm. 28). Masalah, tuntutan, atau kerugian memiliki kemungkinan untuk melemahkan fungsi dan hubungan keluarga, atau sebaliknya, memperkuat keluarga untuk mengatasinya melalui aksi dan komitmen bersama. Keluarga yang tangguh diperkuat melalui penggunaan faktor ketahanan (protektif dan recovery) dalam menghadapi masalahnya. McCubbin dan McCubbin (1993) mengidentifikasi baik factor protektif dan faktor recovery sebagai factor yang bekerja secara sinergis dan bergantian untuk merespon masalah hingga berhasil mengatasi krisis atau tantangan yang dihadapi keluarga. Faktor pelindung memfasilitasi penyesuaian, atau kemampuan untuk mempertahankan integritas dan keberfungsian, juga untuk memenuhi tugas perkembangannya. Ketika keluarga ditantang, faktor-faktor pemulihan diminta mempromosikan kemampuan untuk beradaptasi, atau rebound, dalam situasi krisis. Kemampuan tersebut juga sangat dipengaruhi oleh beratnya stressor yang dihadapi dan 'penumpukan' stressor yang membebani factor proteksi dan recovery dalam keluarga akibat berbagai situasi yang dialami keluarga (McCubbin \& McCubbin, 1993).

Kesimpulannya, resiliensi keluarga lebih dari sekedar bertahan dari krisis, tetapi juga menawarkan potensi bertumbuh dari kesulitan. Dalam mengatasi krisis bersama, sebuah keluarga dapat memunculkan lebih banyak cinta, lebih kuat, dan lebih banyak solusi dalam menghadapi tantangan (Walsh, 1998; White et al., 2004). Ada kalanya tuntutan keluarga melebihi kemampuan keluarga. Ketika ketidakseimbangan ini ada, beberapa kemampuan dapat menggantikan yang lain menuju memperoleh kembali kondisi ekuilibrium. Tentu saja, beberapa proses keluarga gagal beradaptasi dengan hasil jangka pendek dan jangka panjang yang buruk (Patterson, 2002).

\subsection{Aplikasi Konsep Resiliensi Keluarga}

Kerangka resiliensi keluarga sangat relevan dengan praktik klinis dan pemberian layanan sosial. Menurut definisinya, resiliensi melibatkan kekuatan di bawah tekanan akibat krisis dan kesulitan yang berkepanjangan. Berbeda dengan fokus praktik deficit model, pendekatan yang berorientasi pada resiliensi ini menarik keluar kekuatan dan potensi keluarga untuk menghadapi tantangan. 
Selain mengatasi masalah, resiliensi juga melibatkan transformasi dan pertumbuhan positif. Dalam membangun ketahanan relasional, keluarga membentuk ikatan yang lebih kuat dan menjadi lebih banyak solusi dalam menghadapi tantangan masa depan. Jadi, setiap intervensi memiliki manfaat pencegahan (Walsh, 2006).

Kunci utama untuk meningkatkan resiliensi keluarga adalah dengan mengidentifikasi potensi, sikapdan sumber lain yang dapat mengembangkan pertumbuhan keluarga dan merespon keadaan-keadaan yang tidak diinginkan. Asesmen keluarga yang masih bersifat tradisional berlandaskan asumsi-asumsi dan strategi medis yang focus pada analisa patologis dan disfungsi keluarga. Terdapat tiga ciri dari model penanganan keluarga berbasis medis (tradisional): (1) asumsi bahwa persoalan keluarga merefleksikan masalah patologis yang dialami oleh satu atau lebih anggota keluarga; (2) proses asesmen awal biasanya menunjukkan hasil diagnose yang mengidentifikasi sumber disfungsi keluarga tersebut; (3) adanya keyakinan bahwa semakin banyak seseorang tahu tentang permasalahannya, maka akan semakin besar kemungkinan persoalan tersebut diselesaikan. Oleh sebab itu, penanganan atau treatment berfokus pada memperbaiki ketidakmampuan atau keterbatasan dari keluarga itu sendiri (Simon, Murphy\&Smith, 2005).

Perspektif mengenai resiliensi perlahan menggeser konsep asesmen tradisional dengan cara melibatkan kekuatan dan sumber daya yang ada pada keluarga tanpa meminimalisir masalah. Perbedaan lain antara praktik yang bersifat tradisional dan yang berorientasi resiliensi adalah sebagai berikut :

Tabel 2. Perbedaan antara aspek-aspek intervensi yang tradisional dan berorientasi resiliensi

\begin{tabular}{|c|c|c|}
\hline Aspek & \multicolumn{2}{|c|}{ Pendekatan } \\
\hline & Tradisional & Orientasi Resiliensi \\
\hline Fokus dan tujuan & $\begin{array}{l}\text { Mendiagnosa dan memperbaiki } \\
\text { disfungsi keluarga }\end{array}$ & $\begin{array}{l}\text { Mengidentifikasi dan } \\
\text { menggunakan sumber-sumber } \\
\text { yang dimiliki keluarga }\end{array}$ \\
\hline Peran diagnosis & $\begin{array}{l}\text { Prasyarat untuk } \\
\text { treatment }\end{array}$ & $\begin{array}{l}\text { Tidak terlalu penting untuk } \\
\text { keefektifan treatment }\end{array}$ \\
\hline Peran asesmen & $\begin{array}{l}\text { Mengumpulkan informasi dari } \\
\text { masa lalu untuk mengidentifikasi } \\
\text { patologi }\end{array}$ & $\begin{array}{l}\text { Mengidentifikasi kekuatan dan } \\
\text { sumber daya potensial dari } \\
\text { keluarga saat ini }\end{array}$ \\
\hline
\end{tabular}




\begin{tabular}{|c|c|c|}
\hline Memandang masalah & $\begin{array}{l}\text { Masalah mengindikasikan } \\
\text { keluarga mengalami patologi } \\
\text { (keluarga sakit) }\end{array}$ & $\begin{array}{l}\text { Masalah mengindikasikan solusi } \\
\text { yang belum berhasil (keluarga } \\
\text { stuck) }\end{array}$ \\
\hline Memandang keluarga & $\begin{array}{l}\text { Keluarga tidak adekuat dan } \\
\text { membutuhkan bantuan ahli } \\
\text { di luar keluarga }\end{array}$ & $\begin{array}{l}\text { Keluarga penuh dengan sumber } \\
\text { daya dan mampu menyusun } \\
\text { sumber daya yang mereka miliki }\end{array}$ \\
\hline Peran praktisi & Ahli & Kolaborator \\
\hline Bahasa & Deficit-oriented & Strength-oriented \\
\hline Sumber treatment & $\begin{array}{l}\text { Intervensi bersumber dari } \\
\text { praktisi }\end{array}$ & $\begin{array}{l}\text { Intervensi bersumber dari } \\
\text { kekuatan dan resiliensi keluarga }\end{array}$ \\
\hline Sifat treatment & $\begin{array}{l}\text { Problem focused, remediasi } \\
\text { berdasarkan } \\
\text { patologis }\end{array}$ & $\begin{array}{l}\text { Solution-focused, pemberdayaan } \\
\text { berdasarkan kekuatan }\end{array}$ \\
\hline $\begin{array}{l}\text { Penggunaan } \\
\text { dukungan eksternal }\end{array}$ & $\begin{array}{l}\text { Sedikit menggunakan } \\
\text { dukungan dan sumber daya } \\
\text { eksternal }\end{array}$ & $\begin{array}{l}\text { Leluasa menggunakan dukungan } \\
\text { dan sumber daya eksternal }\end{array}$ \\
\hline $\begin{array}{l}\text { Hasil } \\
\text { diinginkan }\end{array}$ & $\begin{array}{l}\text { Menurunkan } \\
\text { keluarga }\end{array}$ & $\begin{array}{l}\text { Meningkatkan } \\
\text { keluarga }\end{array}$ \\
\hline
\end{tabular}

Sumber : Dikutip dari 'Understanding and Fostering Family Resilience' (Simon,Murphy\&Smith,2005).

Begitu pula menurut Hooper (2008), ketika konselor menanamkan dan mempromosikan kerangka resiliensi ke dalam strategi dalam membantu mereka, konselor kemungkinan akan mempertimbangkan dan mengungkap kemungkinan untuk berbagai macam perilaku fungsional dan disfungsional dan lingkungan (Masten \& Coatsworth, 1998) di antara individu dan keluarga. Resiliensi sepertinya menjadi konstruk dan kerangka kerja yang dapat dipertimbangkan bagi konselor ketika bekerja dengan anak-anak maupun orang dewasa. Myers dan Sweeney (2008) menyatakan, konselor profesional berusaha untuk mendorong kesehatan, kondisi kesejahteraan yang positif, melalui intervensi pengembangan, pencegahan, dan peningkatan kesejahteraan. Kerangka resiliensi sejalan dengan kerangka konseling dan memberikan dukungan terhadap gagasan bahwa individu yang mengalami kejadian buruk atau trauma tidak selalu ditakdirkan menjadi psikopatologi, mengalami hubungan yang buruk dan kesulitan berfungsi sebagai orang dewasa. Peluang untuk resiliens dapat terjadi pada berbagai titik sepanjang perjalanan hidup seseorang (Notter et al., 2008, hal. 622). 
Menurut Simon et.al (2005), wawancara merupakan salah satu asesmen yang memegang fungsi penting untuk mengidentifikasi masalah keluarga. Tidak semua keluarga mampu menyelesaikan masalahnya dan kondisi tersebut akan memperburuk keadaan keluarga itu sendiri. Beberapa keluarga kemudian menjalani terapi dengan beragam harapan untuk dapat menyelesaikan masalahnya. Hal inilah yang menjadi pentimbangan penting alam membangun relasi antara klien dengan terapis sehingga menghasilkan outcome terapeutik yang positif. Berbeda dengan wawancara tradisional, wawancara yang bersifat resiliencedriven bertujuan untuk mengeksplorasi keunikan, kekuatan dan kemampuan coping keluarga. Konselor/therapist dapat mengajukan beberapa pertanyaan dan menyimpulkannya berdasarkan kesuksesan keluarga, harga diri, kebahagiaan, kapabilitas dan sumber-sumber resiliensi lainnya. Konselor/therapist juga menggali beberaapa interaksi yang menyenangkan dalam keluarga untuk meningkatkan aspek-aspek positif dalam kehidupan keluarga. Penting juga untuk mengembangkan rapport dan kepercayaan dalam keluarga dengan beragam latar belakang etnis, sosioekonomi dan juga kebudayaan yang berbeda dengan konseloratau therapist. Pujian, dorongan dan motivasi juga penting untuk disampaikan pada keluarga selama proses konseling agar keluarga dapat mencapat resiliensi lebih cepat. Selain itu dalam proses konseling atau terapi diperbolehkan untuk menanyakan tentang krisis atau masalah yang pernah dialami dan bagaimana keluarga menggunakan sumber-sumber internal dan eksternal untuk menyelesaikan permasalahan tersebut.

\subsection{Penelitian Tentang Resiliensi Keluarga}

Penelitian tentang resiliensi keluarga biasanya memandang keluarga sebagai factor proteksi atau resiko. Keluarga yang memiliki karakteristik yang berhubungan dengan penyebab ketahanan individu maka dapat dikatakan keluarga sebagai factor protektif. Namun orangtua yang melakukan penganiayaan pada anak, mungkin dapat dikatakan keluarga tidak berfungsi sebagai factor protektif. Namun beberapa individu yang trauma mungkin memiliki self righting yang baik sehingga ia dapat tetap resiliens meski berada dalam keluarga dan system pengasuhan yang tidak efektif (Gold, 2001; Hooper, 2008). Selain itu, sistem keluarga dapat menjadi faktor risiko di masa kanak-kanak dan jadi factor pelindung ketika anak dewasa untuk individu yang sama. Oleh sebab itu untuk meneliti resiliensi keluarga, seseorang harus memahami konteksnya. Fraser et al. (1999) menyatakan bahwa resiliensi muncul dari heterogenitas individu dan lingkungan yang berpengaruh untuk menghasilkan kinerja luar biasa dalam menghadapi ancaman yang signifikan. Resiliensi individu telah lama dipelajari, namun penelitian dan literature klinis baru saja mulai mengeksplorasi ketahanan keluarga (Walsh, 1996, 1998). Selain itu, resiliensi pada umumnya sering terjadi 
pada tingkat individu dalam konteks unit atau keluarga yang disfungsional; dan dahulu resiliensi keluarga sering diabaikan. (Hooper,2008).

Saat ini penelitian resiliensi keluarga semakin meningkat. Resiliensi keluarga merupakan cara pandang resiliensi yang lebih sistemik, di definisikan untuk keperluan tinjauan proses interaksi dari waktu ke waktu yang dapat memperkuat keluarga (Hawley\&DeHaan,1996). Karakteristik keluarga yang sering dilaporkan sebagai resiliensi lebih banyak tampak pada keluarga yang mengalami kesulitan atau trauma (McCubbin \& Patterson, 1982; Patterson, 2002). Misalnya, kehangatan keluarga, kasih sayang keluarga, dukungan emosional keluarga mungkin tidak ada pada keluarga yang melakukan penganiayaan terhadap anak. Namun, Walsh (1998) berpendapat bahwa jika orang tua tidak dapat menyediakan iklim ini, hubungan dengan anggota keluarga lainnya, seperti saudara yang lebih tua, kakek nenek, dan kerabat jauh dapat melayani fungsi ini.

Lietz (dalam Becvar, 2013) menuliskan bahwa penelitian resiliensi awal banyak dipengaruhi oleh Werner dan Smith (2001) yang selama 40 tahun mempelajari tentang remaja yang beresiko tinggi. Peneliti ini melakukan studi longitudinal yang diikuti oleh 698 bayi yang lahir di Pulau Kauai dalam 1 tahun. Sepertiga dari sampel diidentifikasi sebagai berisiko tinggi. Anak-anak tersebut (a) mengalami stres perinatal, (b) lahir dalam kemiskinan, dan (c) diangkat dalam kondisi keluarga/orangtua yang berselisih, kecanduan, atau memiliki masalah kesehatan mental. Sampel dari remaja yang berpartisipasi tersebut kemudian dinilai setiap 10 tahun. Studi ini membongkar satu set factor pelindung yang muncul, seperti menjaga hubungan dengan setidaknya satu orang dewasa yang peduli, yang banyak membantu anak ini hingga berhasil mengatasi tantangan dan akhirnya berkembang menjadi wellfunctioning. Terpenting dalam studi ini adalah bagaimana kita terdorong untuk meneliti bagaimana factor resiko dan pelindung tersebut bekerjasama untuk keberfungsian yang lebih baik (Garmezy, 1993; Garmezy, Masten, \& Tellegen, 1984; Luthar, 1991; Masten \& Coatsworth, 1998). Penelitian-penelitian tersebut kemudian memberikan kita sebuah kesimpulan bahwa keberhasilan individu mengatasi kesulitan yang dihadapi disebabkan oleh dua hal, yakni personal traits dan factor-faktor protektif dalam keluarga dan konteks sosial (Werner, 1993 ; Wetner\&Smith, 1992).

Penelitian tentang resiliensi keluarga menjadi sangat menarik. Peneliti didorong untuk mampu mengidentifikasi dan mendorong perilaku yang memungkinkan keluarga mengatasi secara efektif krisis, trauma dan tekanan yang dialami keluarga (Walsh, 1996). Resiliensi keluarga juga memungkinkan para peneliti untuk memahami pengaruh moderasi dari proses keluarga dalam berurusan dengan trauma, krisis, atau kejadian buruk. Ini mendorong para peneliti untuk melihat keluarga memiliki kualitas universal, pada saat yang sama mengakui kekuatan dan kelemahan yang unik dan berbeda, serta berbeda lintasan 
dan solusi untuk masalah serupa. Dengan demikian, konstruk ketahanan keluarga menimbulkan pertanyaan ini: 'Bagaimana setiap keluarga, ketika menghadapi kesulitan atau krisis, mengatasi dengan cara yang sehat dan tetap berfungsi ,mengingat banyak faktor yang juga harus dilihat yaitu budaya, tahap siklus hidup

dan faktor lain seperti politik dan masyarakat. Peneliti juga dapat mengkaitkannya dengan factor ketahanan masyarakat (Walsh, 2007) dan pertumbuhan pasca trauma (Hawley\&DeHaan, 1996). Meski begitu, resiliensi keluarga tetap mempertimbangkan bagaimana keluarga bisa kembali ke keadaan fungsi semula, sebelum masalah terjadi, dengan melihat bagaimana keluarga berkembang setelah trauma.

Menurut Walsh (1996) penelitian yang dilakukan berdasarkan topik resiliensi keluarga perlu memperjelas pemahaman atas keluarga, terutama pada keluarga yang berhasil mengatasi gangguan dan tekanan. Metodologi kualitatif dan kuantitatif dapat digunakan dalam penelitian bertopik resiliensi keluarga. Pelu juga dilakukan pendalaman atas system keyakinan keluarga dan konsep keluarga yang mampu berfungsi dengan baik.

\section{KESIMPULAN}

Artikel ini memberikan implikasi positif bagi pengembangan teori, aplikasi dan penelitian dalam kajian tentang resiliensi keluarga. Pandangan negative mengenai keluarga kita telah berubah menjadi positif. Bahkan di saat keluarga mengalami krisis dan permasalahan yang datang bertubi-tubi, masih ada keluarga yang tetap berfungsi secara positif dan membawa keluarga pada kondisi yang resiliens. Tidak ada keluarga yang bebas dari masalah. Konsep resiliensi keluarga ini dapat menjelaskan bagaimana sebuah keluarga memahami dan memaksimalkan potensinya untuk bangkit dalam mengadapi masalah dan tekanan. Lebih lanjut resiliensi keluarga ini dapat diaplikasikan dalam penelitian dan implikasi klinis melalui konseling atau terapi keluarga. Tentu dengan metode dan pendekatan yang positif dimana focus tidak pada problem atau deficit keluarga, namun pada kekuatan sumber daya internal dan eksternal yang dimiliki keluarga untuk menjadi resiliens.

\section{DAFTAR PUSTAKA}

Becvar, D.S. (2013). Handbook of Family Resilience. DOI. 10.1007/978-1-46143917-2. Newyork : Springer. 
Black,K.,\&Lobo,M. (2008). A Conceptual Review of Family Resilience Factors. Journal of Family Nursing,14,33-55.

Hawley, D. R, D. (1996). Toward a Definition of Family Resilience : Integreting life-Span and Family Perspectives.pdf. Family Process, 35(3), 283-98.

Herdiana,I.,Suryanto.,Handoyo,S. (2018). Family Resilience : A Conceptual Review. Advances in Social Science, Education and Humanities Research, volume 133(1984), 42-48.

Hooper, L. M. (2008). Individual and Family Resilience: Definitions, Research, and Frameworks Relevant for All Counselors. Alabama Counseling Association Journal, 35(1), 19-26. Retrieved from http://eric.ed.gov/?id=EJ875400

Luthar, S. S., Cicchetti, D., \& Becker, B. (2000). The construct of resilience: A critical evaluation and guidelines for future work. Child Development, 71. 543-562.

McCubbin, M., \& McCubbin, H. (1993). Families coping with illness: The resiliency model of family stress, adjustment and adaptation. In C. Danielson, B. Hamel-Bissell, \& P. Winstead-Fry (Eds.), Families, health and illness: Perspectives on coping and inter- vention (pp. 21-61). St. Louis, MO: Mosby.

Meldrum,

Patterson, J. (2002). Intergrating family resilience and family stress theory. Journal of Marriage and Family, 64(2), 349-360

Simon,J.B., Murphy, J.J.,Smith,S.M. (2005). Understanding and Fostering Family Resilience. The Family Journal : Counseling and Therapy For Couples and Families, Vol. 13 No. 4, October 2005 427-436, DOI: $10.1177 / 1066480705278724$

Walsh, F. (2006). Strengthening Family Resilience (Second). New York: The Guilford Press.

Walsh, F. (1996). The concept of family resilience: Crisis and challenge. Family Process, 35(3), 261-281. https://doi.org/10.1111/j.1545-5300.1996.00261.x 